\title{
Die woordeboek vir meganiese ingenieurs: Vorderingsverslag
}

Die komitee van die Nasionale Vakterminologiediens (NVD) wat 'n woordeboek vir meganiese ingenieurswese saamstel en in Januarie 1986 met sy werksaamhede begin het, makk goeie vordering. Die dag-tot-dag-werk word deur "n redaksiekomitee behartig wat twee keer maandeliks vergader en uit verteenwoordigers van universiteite, SAVD, YSKOR, SABS en ander instansies bestaan. Die voorsitter is mnr. J.C. de Waal. Terme word uit verskeie bronne - o.a. handbocke - geëkserpeer en deur die NVD in alfabetiese lyste saamgestel. Die lede van die redaksiekomitee moet dan hulle huiswerk doen en die Afrikaanse ekwivalente aanvaar, afkeur, verander of nuwe terme voorstel. Die terme waarop kommentaar gelewer is, word dan by die volgende vergadering van die redaksiekomitee bespreek. Terme moet soms na deskundiges verwys word vir verdere navorsing. Indien die redaksiekomitee in die geval van probleemterme nie tot 'n vergelyk kan kom nie, word die terme na die projekkomitee verwys, wat bestaan uit die lede van die redaksiekomitee sowel as ander deskundiges wat nie in die Pretoria-Johannesburg-gebied woon nie. Hierdie projekkomitee vergader een of twee keer per jaar.

Wat die vordering betref, is die letters $\mathrm{A}$ tot $\mathrm{H}$ (Engels) alreeds redaksioneel versorg, gealfabetiseer, deur 'n sinoniemeprogram van die rekenaar gestuur en as konsep vir gebruik deur komiteelede beskikbaar. Gedurende die vergaderings van die redaksiekomitee word natuurlik nog altyd verbeterings t.o.v. A tot $\mathrm{H}$ aangebring, of vorige besluite hersien, sodat die erratalys steeds groei. Die redaksiekomitee het die letters I tot K ook reeds afgehandel, en na redaksionele versorging deur die NVD sal hulle ook eersdaags in konsepdruk verskyn. In hierdie stadium beloop die getal Engels-Afrikaanse terme reeds meer as 15000 . Al hierdie terme is deur middel van die Nasionale Termbank van die NVD landswyd toeganklik vir navraagdoeleindes. Die letter $\mathrm{L}$ word tans behandel. Terme is tot die letter $\mathrm{S}$ geëkserpeer en die lede van die redaksiekomitee het tot by letter $\mathrm{M}$ kommentaar op die lyste gelewer.

Die goeie vordering beteken nie dat die komitee nie met probleme te kampe het nic. Trouens, daar is nog vraagstukke wat nie finaal opgelos is nie. Sommige van hierdie probleme is in die verlede in hierdie rubriek behandel in die hoop dat lesers kommentaar daarop sal lewer. Ongelukkig het daar egter nie veel van gekom nie; dus is daar nog probleme hangende.

Die volgende taalprobleme is in die verlede in hierdie rubriek aangeroer:

Saamskryf of gebruik van koppeltekens by saamgestelde terme (Nr. 1, 1989, bl. 37).

"Krities" of "kritiek" (Nr. 2, 1987, bl. 89). [Hierop het dr. D.F. Louw in Nr. 4, 1987, bl. 169 kommentaar gelewer en hy word hartlik daarvoor bedank. I

“Altitude" of "hoogte bo seespieël” (Nr. 2, 1987, bl. 89).

Persoonsname in vakterme (Nr. 2, 1987, bl. 89).

"Girder" vertaal as "draer" en nie as "leer" nie ( $\mathrm{Nr}$ 2, 1987, bl. 89).

Warmte en hitte (Nr. 3, 1986, bl. 164).

Daar word dus weer eens 'n beroep op die lesers van hierdie rubriek gedoen om te reageer en hulle kommentaar en kritiek te stuur aan die Nasionale Vakterminologiediens, Privaat sak X122, Pretoria 000I of aan die redaksie van hierdie tydskrif. 